\title{
Note on the seed morphology of Entada polyphylla (Leguminosae, Mimosoideae) and its taxonomic significance in E. sect. Entadopsis
}

\author{
Rodrigo Schütz Rodrigues ${ }^{1}$ \\ 1. Universidade Federal de Roraima, Centro de Estudos da Biodiversidade, Campus do Paricarana, Av. Ene Garcez \\ 2413, CEP 69310-000, Boa Vista, Roraima, Brasil. E-mail: rodrigo.schutz@ufrr.br \\ Recebido em: 27/03/2015 Aceito em: 27/04/2015 Publicado online em PDF: 04/05/2015.

\section{RESUMO} \\ Nota sobre a morfologia da semente de Entada polyphylla (Leguminosae, Mimosoideae) e sua significância taxonômica em \\ E. sect. Entadopsis. Entada sect. Entadopsis (Leguminosae, Mimosoideae) abrange três espécies neotropicais, E. polyphylla, E. \\ polystachya e E. simplicata. Esta nota descreve e ilustra a morfologia da semente de Entada polyphylla, procurando avaliar sua \\ relevância taxonômica em $E$. sect. Entadopsis. Os resultados demonstram que as sementes são variáveis na seção, fornecendo ca- \\ racteres taxonômicos úteis em nível específico. As sementes de Entada polyphylla podem ser distintas daquelas de E. polystachya e \\ E. simplicata especialmente pelos caracteres do embrião.
}

PALAVRAS-CHAVE: Embrião, Fabaceae, leguminosas, Mimoseae, testa.

\section{ABSTRACT}

Note on the seed morphology of Entada polyphylla (Leguminosae, Mimosoideae) and its taxonomic significance in $E$. sect. Entadopsis. Entada sect. Entadopsis (Leguminosae, Mimosoideae) encompasses three Neotropical species, E. polyphylla, E. polystachya, and E. simplicata. This note describes and illustrates the seed morphology of Entada polyphylla, aiming to evaluate its taxonomic value within E. sect. Entadopsis. The results support the view that seeds are quite variable in the section, providing taxonomic characters useful at the species level. Seeds of Entada polyphylla can be distinguished from those of E. polystachya and E. simplicata especially by their embryo characters.

KEY WORDS: Embryo, Fabaceae, legume, Mimoseae, testa.

\section{INTRODUCTION}

Entada Adans. (Leguminosae, Mimosoideae) comprises 28 species (Luckow 2005). In Brazil, only three species have been recorded, especially along the Amazon basin (Rodrigues \& Flores 2012): E. polyphylla Benth., E. polystachya (L.) DC., and E. simplicata (Barneby) Sch. Rodr. \& A.S. Flores. These species belong to E. sect. Entadopsis (Britton) Brenan and occur exclusively in the Neotropics (Brenan 1966; Rodrigues \& Flores 2012).

Seed morphology is taxonomically useful in Entada (Brenan 1966; Gunn 1984), especially regarding its Old World species (Brenan 1966; Lungu \& Culham 1996; Tateishi et al. 2008). In addition, Rodrigues et al. (2014) found several quantitative and qualitative differences between seeds of E. polystachya and E. simplicata. Nevertheless, to my knowledge, no previous study concerning seed morphology of $E$. polyphylla has been carried out. This species occurs mainly along the Amazon Basin, with records to Puerto Rico (Barneby 1996).

This note describes and illustrates the seed morphology of Entada polyphylla, aiming to evaluate its taxonomic value within $E$. sect. Entadopsis.

Descriptive terminology and methods followed Gunn (1984) and Rodrigues et al. (2014). Vouchers are housed at the Herbarium of the Museu Integrado de Roraima (MIRR): E. S. Braga et al. 73 and E. S. Braga et al. 74. 


\section{RESULTS AND DISCUSSION}

Seeds of Entada polyphylla - Seeds 20-24 $\mathrm{mm}$ long, $10-13 \mathrm{~mm}$ wide, $1-1.5 \mathrm{~mm}$ thick, oblong to elliptic, flattened, symmetrical (Figure 1A), and in a single transverse nonoverlapping series. Testa dark brown, chartaceous, smooth, pleurogrammatic, having a $90-100 \%$ pleurogram (Figures 1A, C), adnate patches of endocarp tissues absent; fracture lines absent (Figure 1C); funicular impression on the testa surface near the seed apex absent. Hilum punctiform, apical (Figure 1B), aril absent. Lens 0.5-0.6 mm long, with similar color to the testa, shorter than the radicle lobe in height. Endosperm absent. Cotyledons 19$22.2 \mathrm{~mm}$ long, $9.5-12.3 \mathrm{~mm}$ wide, $0.5-0.8 \mathrm{~mm}$ thick, oblong to elliptic, with a strongly asymmetric lobed base (Figures 2A-E) and a rounded apex; cotyledon lobes $0.8-1 \mathrm{~mm}$ long; cotyledonary petioles $0.7-1 \mathrm{~mm}$ long (Figures 2B-D), Radicle 0.6-1 mm long, 0.8-1 mm wide, triangular to ovate (Figure 2A-B), exposed, notched. Plumule $0.7-1 \mathrm{~mm}$ long, moderately developed, bipartite (Figures 2D-E).
Seeds of Entada sect. Entadopsis - This work provides data for E. polyphylla seeds that can be compared with those of the other two species of E. sect. Entadopsis, E. polystachya and E. simplicata (Rodrigues et al. 2014). There are several seed traits shared by the three species of E. sect. Entadopsis. Their seeds are oblong to elliptic, flattened, symmetrical and in a single transverse non-overlapping series. The testa is dark brown, chartaceous, pleurogrammatic, having a $90-100 \%$ pleurogram. The hilum is punctiform, apical, and both aril and endosperm are absent. The embryo has oblong to elliptic cotyledons, with a lobed base and a rounded apex. The embryonic axis is straight, and the plumule is moderately developed.

Although seeds of E. polyphylla superficially resemble those of the other two species of E. sect. Entadopsis, some embryo characters markedly provide to be diagnostic (Table 1). Entada polyphylla has developed cotyledonary petioles $(0.7-1 \mathrm{~mm}$ long), whereas both E. polystachya and E. simplicata have inconspicuous cotyledonary petioles
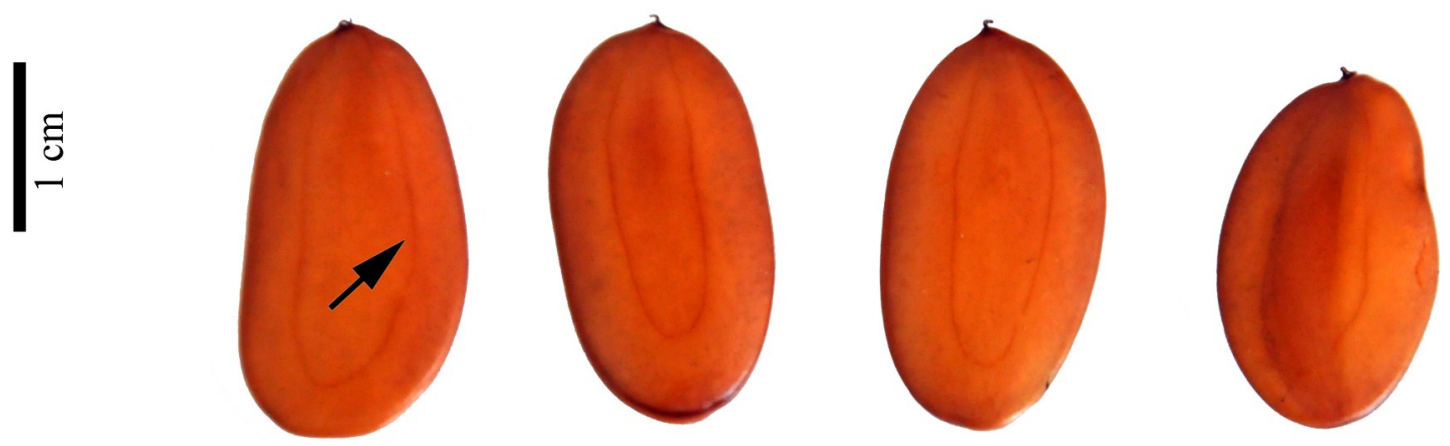

A
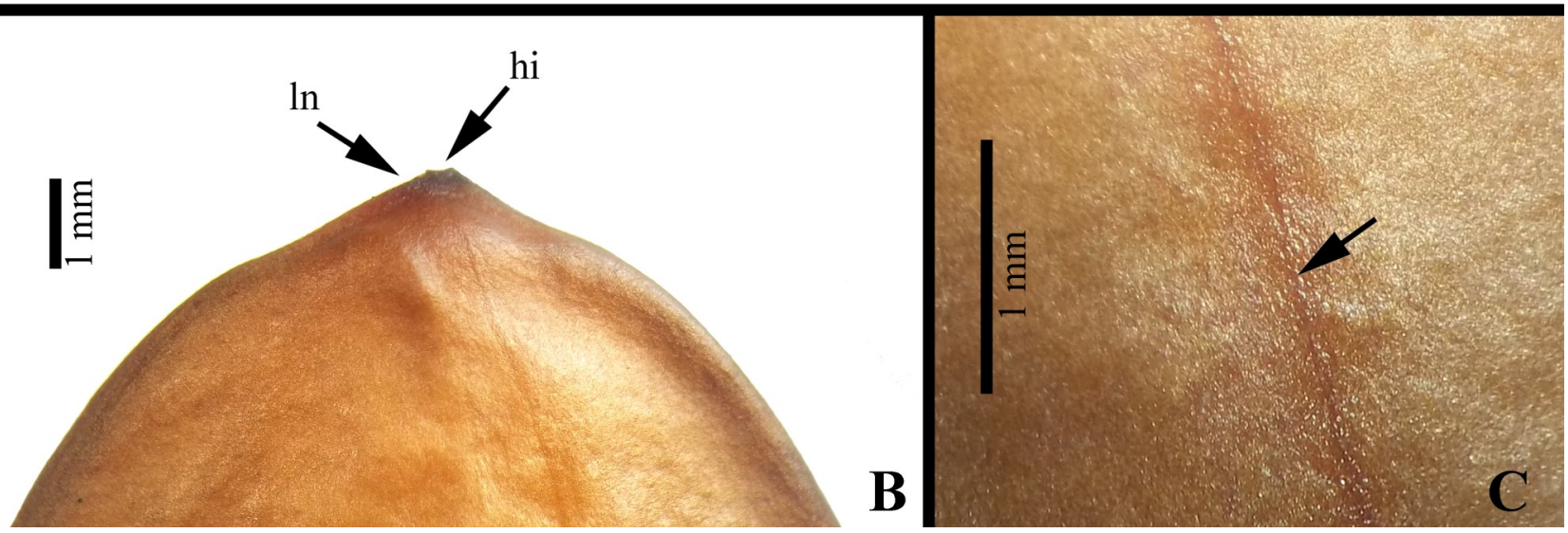

Figure 1. Seed morphology of Entada polyphylla Benth. A. Seeds. B. Detail of the hilum region, showing the lens (ln) and the hilum (hi). C. Detail of the testa, showing the pleurogram (arrow); observe that fracture lines are lacking (E. S.

Braga et al. 74). 


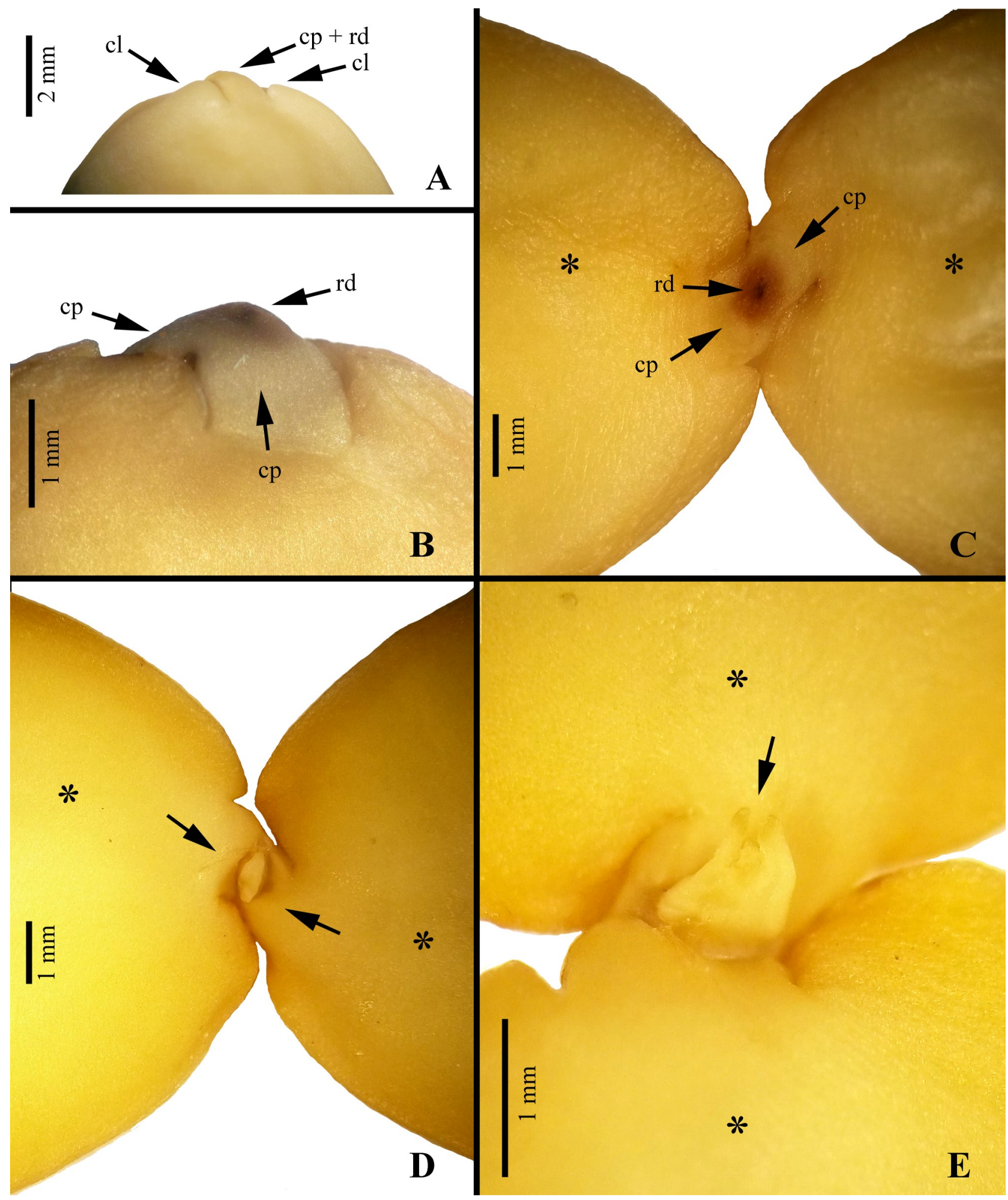

Figure 2. Embryo of Entada polyphylla Benth. A. Cotyledon lobes (cl), showing a fully exposed radicle (rd) and a cotyledonary petiole (cp). B. View of the radicle (rd) and cotyledonary petioles (cp) region. C. Abaxial view of both cotyledons (asterisks), showing the cotyledonary petioles(cp) and the radicle (rd). D. Adaxial view of both cotyledons (asterisks), arrows showing the cotyledonary petioles. E. Adaxial view of both cotyledons (asterisks), arrow showing the plumule (E. S. Braga et al. 74).

(Rodrigues et al. 2014). In E. polyphylla, short ( $\leq 1 \mathrm{~mm}$ long). On the other hand, both cotyledon lobes are asymmetrical and relatively E. polystachya and E. simplicata have 
Table 1. Summary of seed diagnostic characters in Entada sect. Entadopsis taxa.

\begin{tabular}{|l|l|l|l|}
\hline Characters/Taxa & E. polyphylla & E. polystachya & E. simplicata \\
\hline $\begin{array}{l}\text { Testa fracture } \\
\text { lines }\end{array}$ & absent & present & absent \\
\hline $\begin{array}{l}\text { Testa funiculus } \\
\text { impression }\end{array}$ & absent & absent & generally present \\
\hline $\begin{array}{l}\text { Relative height of } \\
\text { lens to radicle }\end{array}$ & $\begin{array}{l}\text { shorter than the radicle } \\
\text { lobe }\end{array}$ & equal to radicle lobe & $\begin{array}{l}\text { shorter than the radicle } \\
\text { lobe }\end{array}$ \\
\hline Lens coloration & similar to testa & dissimilar to testa & similar to testa \\
\hline petioles & $\begin{array}{l}\text { developed, 0.7-1 mm } \\
\text { long }\end{array}$ & inconspicuous & inconspicuous \\
\hline Cotyledon lobes & $\begin{array}{l}\text { asymmetrical; } 0.8-1 \\
\text { mm long }\end{array}$ & $\begin{array}{l}\text { symmetrical; 2.8-3.8 mm } \\
\text { long }\end{array}$ & $\begin{array}{l}\text { symmetrical; } \\
\text { mm long }\end{array}$ \\
\hline Radicle & $\begin{array}{l}\text { triangular; 0.6-1.8 } \mathrm{mm} \\
\text { long, fully exposed }\end{array}$ & $\begin{array}{l}\text { bulbose; 3.7-4.7 mm } \\
\text { long, partially exposed }\end{array}$ & $\begin{array}{l}\text { triangular; 2.4-2.7 mm } \\
\text { long, partially exposed }\end{array}$ \\
\hline Data source & present work & Rodrigues et al. (2014) & Rodrigues et al. (2014) \\
\hline
\end{tabular}

symmetrical and longer cotyledon lobes $(\geq 1.5$ $\mathrm{mm}$ long) (Rodrigues et al. 2014). In addition, E. polyphylla has a short $(\leq 1 \mathrm{~mm}$ long) and fully exposed radicle, while both $E$. polystachya and E. simplicata possess a longer $(\geq 2.4 \mathrm{~mm}$ long) and partially exposed radicle (Rodrigues et al. 2014).

As a conclusion, the results obtained here for Entada polyphylla reinforce that seeds are quite variable in E. sect. Entadopsis (Rodrigues et al. 2014), providing taxonomic characters useful at the species level. Entada polyphylla seeds can be distinguished from those of $E$. polystachya and E. simplicata especially by their embryo characters.

\section{ACKNOWLEDGMENTS}

I thank Dr. Andréia Flores (Museu Integrado de Roraima) and Elivane Braga (Universidade Federal de Roraima), who kindly provide me seeds for this study; CBio/UFRR for facilities.

\section{REFERENCES}

Barneby, R.C. 1996. Neotropical Fabales at NY: asides and oversights. Brittonia 48(2): 174-187.
Brenan, J.P.M. 1966. Notes on Mimosoideae: XI: The Genus Entada, its subdivisions and a key to the African species. Kew Bulletin 20(3): 361-378.

Gunn, C.R. 1984. Fruits and seeds of genera in the subfamily Mimosoideae (Fabaceae). United States Department of Agriculture Technical Bulletin 1681: 1 $-194$.

Luckow, M. 2005. Mimoseae. In: Lewis, G.; Schrire, B.; Mackinder, B. \& Lock, M. (Ed.). Legumes of the World. Royal Botanic Gardens, Kew, p. 163-183.

Lungu, S. \& Culham, A. 1996. Seed and seedling morphology of Entada, a study of Zambian species. In: van der Maesen, L.J.G.; van der Burgt, X.M. \& van Medenbach de Rooy, J.M. (Ed.). The Biodiversity of African Plants. Kluwer Academic Publishers, Dordrecht, p. 809-814.

Rodrigues, R.S.; Feitoza, G.V. \& Flores, A.S. 2014. Taxonomic relevance of seed and seedling morphology in two Amazonian species of Entada (Leguminosae). Acta Amazonica 44(1): 19-24.

Rodrigues, R.S. \& Flores, A.S. 2012. A new combination in Entada (Leguminosae) from Roraima, Brazil. Phytotaxa 39: 47-50.

Tateishi, Y.; Wakita, N. \& Kajita, T. 2008. Taxonomic revision of the genus Entada (Leguminosae) in the Ryukyu Islands, Japan. Acta Phytotaxonomica et Geobotanica, 59(3): 194-210. 